\title{
Synthesis, Characterization, and Pharmacological Evaluation of Selected Aromatic Amines
}

\author{
Hammad Ismail, ${ }^{1}$ Bushra Mirza, ${ }^{1}$ Ihsan-ul Haq, ${ }^{2}$ Muhammad Shabbir, ${ }^{3}$ \\ Zareen Akhter, ${ }^{3}$ and Amina Basharat ${ }^{3}$ \\ ${ }^{1}$ Department of Biochemistry, Quaid-i-Azam University, Islamabad 45320, Pakistan \\ ${ }^{2}$ Department of Pharmacy, Quaid-i-Azam University, Islamabad 45320, Pakistan \\ ${ }^{3}$ Department of Chemistry, Quaid-i-Azam University, Islamabad 45320, Pakistan
}

Correspondence should be addressed to Bushra Mirza; bushramirza@qau.edu.pk

Received 3 December 2014; Revised 24 January 2015; Accepted 25 January 2015

Academic Editor: Shu Taira

Copyright $\odot 2015$ Hammad Ismail et al. This is an open access article distributed under the Creative Commons Attribution License, which permits unrestricted use, distribution, and reproduction in any medium, provided the original work is properly cited.

Aromatic amines 1-amino-4-phenoxybenzene (A-1A), 2-(4-aminophenoxy) naphthalene (A-2A), and 1-(4-aminophenoxy) naphthalene $(\mathrm{A}-3 \mathrm{~A})$ were synthesized by the reduction of corresponding nitroaromatics with hydrazine monohydrate and $\mathrm{Pd} / \mathrm{C} 5 \%$ $(\mathrm{w} / \mathrm{w})$. The newly synthesized compounds were characterized by FTIR, ${ }^{1} \mathrm{H}$ NMR, ${ }^{13} \mathrm{C}$ NMR, UV-visible spectrophotometer, and mass spectrometry and their biological activities were investigated along with structurally similar 4-(4-aminophenyloxy) biphenyl (A-A). Results of brine shrimp cytotoxicity assay showed that almost all of the compounds had $\mathrm{LD}_{50}$ values $<1 \mu \mathrm{g} / \mathrm{mL}$. The compounds also showed significant antitumor activity with $\mathrm{IC}_{50}$ values ranging from 67.45 to $12.2 \mu \mathrm{gmL}^{-1}$. The cytotoxicity and antitumor studies correlate the results which suggests the anticancerous nature of compounds. During the interaction study of these compounds with DNA, all of the compounds showed hyperchromic effect indicating strong interaction through binding with the grooves of DNA. Moreover, A-3A also showed decrease in $\lambda_{\max }$ confirming higher propensity for DNA groove binding. In DPPH free radical scavenging assay, all the compounds showed potential antioxidant capability. The compounds were highly active in protecting DNA against hydroxyl free radicals. DNA interaction and antioxidant results back up each other indicating that these compounds have potential to be used as cancer chemopreventive agents. Additionally, one compound (A-1A) showed significant antibacterial and antifungal activity as well.

\section{Introduction}

Aromatic amines are a class of organic compounds in which an amino $\left(-\mathrm{NH}_{2}\right)$ group is directly attached to aromatic carbon. These are used for the synthesis of many compounds like azo dyes [1], Schiff's bases [2], zeolites [3], polyimides, polyamides [4], stationary phase for HPLC [5], epoxy resins [6], and plastics [7]. These compounds also act as a catalyst for the cross-linking of polyester, a stabilizer for phenolic resins, coagulants, and antiknock additives for gasoline and diesel fuel [7]. Due to their biological activities, amines are also named as alkaloids in phytochemistry. Amine group bearing hydrazide hydrazones is a class of compounds possessing numerous biological activities like antitumor, antimycobacterial, antimicrobial, inhibitor of anthrax lethal factor, antiinflammatory, trypanocidal, leishmanicidal, antidiabetic, and antimalarial agents [8]. Paclitaxel is an amine containing chemotherapy drug that can be used to treat cancers [9].

It is believed that oxidative processes encourage carcinogenesis, even though the mechanisms for this are not well defined [10]. The main mechanism proposed for protective action against harmful oxidative processes is associated with the free radical scavenging activity of antioxidant compounds [11]. The antioxidants may cause the deterioration of premalignant tumors and inhibit their expansion into cancer [10]. Initial studies have reported that some antioxidants, like $\beta$ carotene, may be of advantage in the treatment of precancerous circumstances such as oral leukoplakia, probably a precursor of oral cancer [10].

It is of immense help to recognize the structural properties of DNA, the cause of some diseases, and mechanism of some antivirus and antitumor drugs, to design efficient and 
new DNA targeted drugs to deal with diseases [12]. A drug can interact with DNA by two ways, either by intercalation or as grooves binders. Grooves binders drugs interact with DNA either at minor groove or at major groove. While binding with minor groove, the drug interacts with walls of the groove and hydrogen bonding is established or electrostatic interactions occur with the bases and the phosphate backbone. On the other hand, drug establishes hydrogen bonding with major groove, forming a triple helix of DNA [13]. Both groove binders and intercalating agents are typified as antiviral, antibacterial, antifungal, and antitumor agents [14-16].

In the present study, new aromatic amines were synthesized and biological potential was evaluated along with one previously reported compound (A-A) [17] due to structural similarity. These compounds were screened by using brine shrimp cytotoxicity assay followed by potato disc antitumor assay, antibacterial assay, antifungal assay, DPPH free radical scavenging assay, and DNA damage assay. Also these compounds were investigated for the interaction with DNA to understand their possible mechanism of action in cancer chemoprevention.

\section{Experimental}

2.1. Materials. All the reagents used were of analytical grade. $\mathrm{Pd} / \mathrm{C} 5 \%(\mathrm{w} / \mathrm{w})$, hydrazine monohydrate $(\geq 98 \%)$, and ethanol ( $\geq 97 \%$ ) were used as acquired from supplier. 4-(4Nitrophenyloxy) biphenyl, 1-nitro-4-phenoxybenzene, 2-(4nitrophenoxy) naphthalene, and 1-(4-nitrophenoxy) naphthalene used were synthesized by our research group and were recrystallized for further use. Solvents used were dried and purified according to standard procedures [18]. The reactions were carried out in an inert atmosphere by purging dry $\mathrm{N}_{2}$ gas. The pace of reactions and purity of products were checked by thin layer chromatography on precoated Kieselgel 60 HF TLC plates. Elemental analysis was carried out on a CHNS 932 (Leco, USA) elemental analyzer. Melting points were determined on Gallen Kamp apparatus and are uncorrected. Infrared measurements $\left(4000-400 \mathrm{~cm}^{-1}\right)$ were taken on Thermoscientific NICOLET 6700 FTIR spectrophotometer. ${ }^{1} \mathrm{H}$ NMR and ${ }^{13} \mathrm{C}$ NMR spectra were obtained on a Bruker $300 \mathrm{MHz}$ NMR spectrophotometer in deuterated chloroform using tetramethylsilane as internal reference. GC-MS spectra were recorded in methanol on a micromass platform II instrument.

2.2. General Procedure for the Synthesis of Aromatic Amines. Aromatic amines were synthesized by a reported procedure [19]. Mixture of corresponding nitroaromatic compound, hydrazine monohydrate, and $\mathrm{Pd} / \mathrm{C} 5 \%(\mathrm{w} / \mathrm{w})$ was refluxed in ethanol for 18 hours in $250 \mathrm{~mL}$ flask equipped with a magnetic stirrer under an inert atmosphere created by purging dry nitrogen. After the completion of reaction, $\mathrm{Pd} / \mathrm{C}$ was removed by filtering the hot mixture. Concentrating the filtrate on rotary evaporator resulted in precipitation. The precipitates were separated by filtration and recrystallized from methanol [20] (Scheme 1).

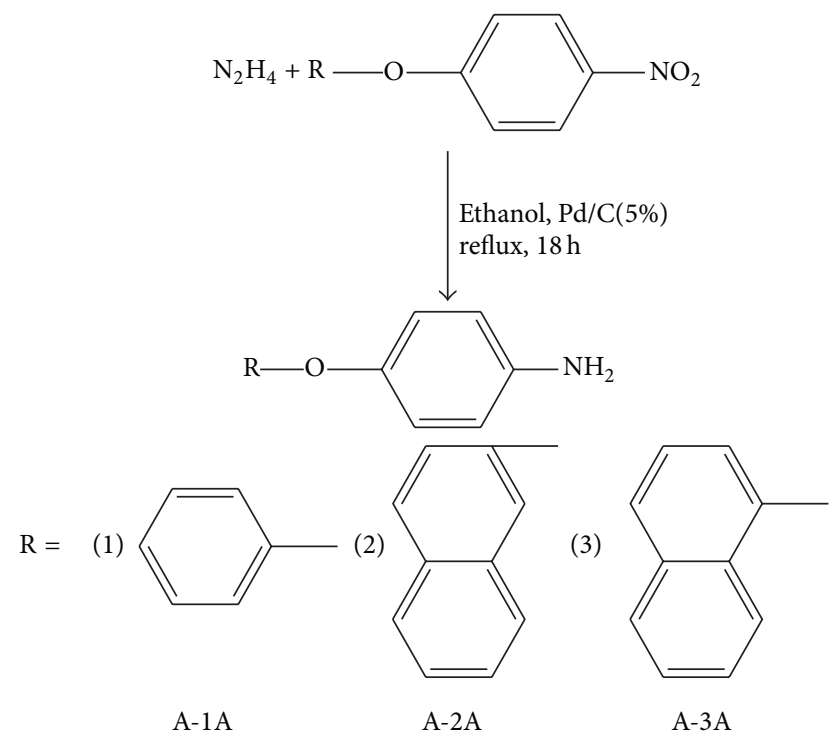

Scheme 1: General scheme for the aromatic amine synthesis.

2.2.1. Synthesis of 1-Amino-4-phenoxybenzene (A-1A). 1Amino-4-phenoxybenzene (A-1A) was synthesized using $2.00 \mathrm{~g} \quad(9.30 \mathrm{mmol})$ 1-nitro-4-phenoxybenzene, $5.00 \mathrm{~mL}$ hydrazine monohydrate, and $0.05 \mathrm{~g} \mathrm{Pd} / \mathrm{C} 5 \%$ (w/w).

Color: yellow, Yield $79 \%$, melting point $83^{\circ} \mathrm{C}$. FT-IR: $\left(v / \mathrm{cm}^{-1}\right)(\mathrm{N}-\mathrm{H})$ 3391(asym) 3315(sym), (C-O-C) 1225, (aromatic $\mathrm{C}=\mathrm{C})$ 1597. ${ }^{1} \mathrm{H} \mathrm{NMR}\left(\mathrm{CDCl}_{3}, \delta \mathrm{ppm}\right): 3.99(2 \mathrm{H}$, $\mathrm{s}, \mathrm{NH}_{2}$ ), 7.33-6.57 (m, aromatic ring protons, ${ }^{13} \mathrm{C} \mathrm{NMR}$ $\left(\mathrm{CDCl}_{3}, \delta \mathrm{ppm}\right): 159.44,145.93,130.12,122.17,121.39,118.47$, 116.85, 115.334, MS ( $\mathrm{m} / \mathrm{z}): 185\left(\mathrm{M}^{+}\right) \mathrm{CHN}$ found (calcd) for $\mathrm{C}_{12} \mathrm{H}_{11} \mathrm{NO}$ : C: 77.89 (77.84), H: 5.87 (5.95), N: 7.52 (7.57), UVvis: $\lambda_{\max }(\mathrm{nm}) 241$.

2.2.2. Synthesis of 2-(4-Aminophenoxy) Naphthalene (A-2A). 2-(4-Aminophenoxy) naphthalene (A-2A) was prepared by mixing $2.00 \mathrm{~g}$ (6.94 mmol) 2-(4-nitrophenoxy) naphthalene, $5.00 \mathrm{~mL}$ hydrazine monohydrate, and $0.05 \mathrm{~g} \mathrm{Pd} / \mathrm{C} 5 \%(\mathrm{w} / \mathrm{w})$, following the general procedure for synthesis of aromatic amines as outlined in Section 2.2.

Color: reddish brown, Yield $75 \%$, melting point $116^{\circ} \mathrm{C}$. FTIR: $\left(v / \mathrm{cm}^{-1}\right)(\mathrm{N}-\mathrm{H})$ 3393(asym) 3323(sym), (C-O-C) 1247, (aromatic $\mathrm{C}=\mathrm{C}) 1622,{ }^{1} \mathrm{H} \mathrm{NMR}\left(\mathrm{CDCl}_{3}, \delta \mathrm{ppm}\right)$ : $4.04\left(2 \mathrm{H}, \mathrm{s}, \mathrm{NH}_{2}\right), 7.89-6.23\left(\mathrm{~m}\right.$, aromatic ring protons), ${ }^{13} \mathrm{C}$ $\mathrm{NMR}\left(\mathrm{CDCl}_{3}, \delta \mathrm{ppm}\right): 157.49,146.17,145.81,134.43,130.20$, $129.48,128.02,127.23,126.98,124.56,121.59,119.24,110.85 . \mathrm{MS}$ $(\mathrm{m} / z): 235\left(\mathrm{M}^{+}\right) \mathrm{CHN}$ found (calcd) for $\mathrm{C}_{16} \mathrm{H}_{13} \mathrm{NO}: \mathrm{C}: 81.44$ (81.07), H: 5.51 (5.53), N: 5.92 (5.96), UV-vis: $\lambda_{\max }$ (nm), 222.

2.2.3. Synthesis of 1-(4-Aminophenoxy) Naphthalene (A-3A). 1-(4-Aminophenoxy) naphthalene (A-3A) was prepared by reaction of $2.00 \mathrm{~g}$ (6.94 mmol) 1-(4-nitrophenoxy) naphthalene, $5.00 \mathrm{~mL}$ hydrazine monohydrate, and $0.05 \mathrm{~g} \mathrm{Pd} / \mathrm{C} 5 \%$ $(\mathrm{w} / \mathrm{w})$ under the conditions maintained for the synthesis of 2-(4-aminophenoxy) naphthalene (A-2A). 
Color: brown, Yield 74\%, melting point $55^{\circ} \mathrm{C}$, FT-IR: $\left(v / \mathrm{cm}^{-1}\right)(\mathrm{N}-\mathrm{H})$ 3400(asym), 3327(sym), (C-O-C) 1242, (aromatic $\mathrm{C}=\mathrm{C})$ 1592. ${ }^{1} \mathrm{H} \mathrm{NMR}\left(\mathrm{CDCl}_{3}, \delta \mathrm{ppm}\right): 4.01(2 \mathrm{H}$, $\left.\mathrm{s}, \mathrm{NH}_{2}\right), 8.25-6.61$ (m, aromatic ring protons), ${ }^{13} \mathrm{C} \mathrm{NMR}$ $\left(\mathrm{CDCl}_{3}, \delta \mathrm{ppm}\right): 155.25,146.29,146.07,134.83,128.10,127.11$, $126.50,125.77,121.94,121.85,121.31,115.40,110.10$, MS $(\mathrm{m} / z)$ : 235 $\left(\mathrm{M}^{+}\right) \mathrm{CHN}$ found (calcd) for $\mathrm{C}_{16} \mathrm{H}_{13} \mathrm{NO}$ : C: 81.84 (81.07), H: 5.59 (5.53), N: 5.94 (5.96), UV-vis: $\lambda_{\max }$ (nm) 215.

\subsection{Biological Assays}

2.3.1. Brine Shrimp Cytotoxicity Assay. Brine shrimp cytotoxicity assay was used to determine the toxicity of the compounds [21]. Artemia salina (brine shrimp) eggs (Ocean Star Inc., USA) were hatched in seawater $\left(34 \mathrm{gL}^{-1}\right)$. After $24 \mathrm{~h}$, ten shrimps were transferred to each vial using Pasteur pipette. The compounds with final concentrations of 10, 1, 0.5, $0.25,0.125$, and $0.0625 \mu \mathrm{gmL}^{-1}$ were added and the volume was raised up to $5 \mathrm{~mL}$ of artificial seawater. Vincristine sulphate was used as positive control and DMSO was used as negative control. The experiment was performed in triplicate and vials were incubated under illumination at $28^{\circ} \mathrm{C}$. After $24 \mathrm{~h}$, survivors were counted and $\mathrm{LD}_{50}$ (lethal dose) values were calculated by using the Finney software [22].

2.3.2. Potato Disc Antitumor Assay. Potato disc antitumor method [23] was used to test the antitumor activity of the compounds. Inoculum was prepared with three concentrations $\left(10,100\right.$, and $\left.1000 \mu \mathrm{gmL}^{-1}\right)$ of sample containing Agrobacterium tumefaciens. Potatoes were surface sterilized with $0.1 \%$ mercuric chloride and $5 \mathrm{~mm} \times 8 \mathrm{~mm}$ potatoes cylinders were placed on agar plates. Then $50 \mu \mathrm{L}$ of inoculum was applied to the top of each disc (10 discs per plate). Vincristine sulphate was used as positive control and DMSO was used as negative control. Experiment was performed in triplicate and plates were placed at $28^{\circ} \mathrm{C}$. After 28 days, discs were stained with Lugol's solution (10\% KI and 5\% $\left.\mathrm{I}_{2}\right)$ and the number of tumors was counted. Percentage inhibition was determined as follows:

$$
\text { Percentage inhibition }=100-\left[\left(\frac{X}{Y}\right) \times 100\right],
$$

where $X$ is average number of tumors of test sample and $Y$ is average number of tumors of -ve control.

2.3.3. DNA-Drug Interaction Assay. Interaction of compounds with DNA was studied by using UV spectrophotometer method [24] with little modifications. InnuPREP blood DNA mini kit (Analytik Jena) was used for the extraction of genomic DNA from human blood and concentration was calculated at $260 \mathrm{~nm}$ by applying the extinction coefficient of $6600 \mathrm{M}^{-1} \mathrm{~cm}^{-1}$ [25]. The working DNA solution $(100 \mathrm{mM})$ was prepared and all the compounds were dissolved in SM (solvent mixture, consisting of methanol and water 9:1). Molar concentrations of compounds were adjusted on the spectrophotometer to ensure that absorbance was between 0.1 and 1 at $\lambda_{\max }$ so that Beer-Lambert law could be applied. The spectrum was recorded and, to this, DNA was stepwise added starting from the lowest concentration to higher concentrations $\left(0.5 \times 10^{-6}, 1 \times 10^{-6}, 0.5 \times 10^{-5}\right.$, and $\left.1 \times 10^{-5} \mathrm{M}\right)$ keeping the compound concentration in the reaction mixture constant. To attain the stable interaction, reaction mixture was allowed to stay for $5 \mathrm{~min}$ before each measurement. SM was used as blank and spectra were recorded in the form of spectral peaks.

2.3.4. DPPH Free Radical Scavenging Assay. Radical scavenging activity of compounds was determined spectrophotometrically [26] at 200, 66.6, 22.4, 7.4, and $2.4 \mu \mathrm{gmL}^{-1}$ final concentration. DPPH $(0.1 \mathrm{mM})$ was prepared in methanol. Ascorbic acid and DMSO were used as positive and negative control, respectively. Each concentration was assayed in triplicate and reaction mixture was incubated at $37^{\circ} \mathrm{C}$ in the dark. After 30 minutes, absorbance was measured at $517 \mathrm{~nm}$ on a UV-vis spectrophotometer (Agilent 8453, G1103A). The percent scavenging of DPPH free radical for each concentration of each test compound was calculated by the following formula:

$$
\text { Percentage Scavenging }=\left[\left(\frac{X-Y}{X}\right) \times 100\right] \text {, }
$$

where $X$ is absorbance of control and $Y$ is absorbance of test sample.

2.3.5. DNA Damage Assay. DNA protection activity of the compounds against oxidative DNA damage was evaluated in vitro by DNA damage assay $[12,27]$. The reaction was carried out in a PCR tube with $15 \mu \mathrm{L}$ of total volume having $3 \mu \mathrm{L}$ pBR322 DNA $(0.5 \mu \mathrm{g}), 3 \mu \mathrm{L}$ of $2 \mathrm{mM} \mathrm{FeSO}_{4}, 4 \mu \mathrm{L}$ of $30 \% \mathrm{H}_{2} \mathrm{O}_{2}$, and $5 \mu \mathrm{L}$ of tested compound with 1000,100 , and $10 \mu \mathrm{gmL}^{-1}$ final concentration. A positive control was used which contains pBR322 DNA treated with $2 \mathrm{mM} \mathrm{FeSO}_{4}+$ $30 \% \mathrm{H}_{2} \mathrm{O}_{2}$, and untreated pBR322 DNA was used as negative control (P). A control containing compound and untreated pBR322 $(\mathrm{C}+\mathrm{P})$ was also used to check the damaging or protective effect of compound on DNA. Then the mixture was incubated at $37^{\circ} \mathrm{C}$ for $1 \mathrm{~h}$. All reaction mixtures were subjected to $1 \%$ agarose gel electrophoresis in $1 \mathrm{X}$ TBE buffer using $1 \mathrm{~kb}$ ladder (L). Gels were analyzed by scanning with Gel-Doc (Bio Rad) computer program and intensity of the bands was determined.

2.3.6. Antibacterial Assay (96-Well Plate Method). Antibacterial activity of compounds was determined by "microtiter plate method" [28] with minor modifications. Five strains of bacteria two Gram positive (Micrococcus luteus (ATCC 10240) and Staphylococcus aureus (ATCC 6538)) and three Gram negative (Bordetella bronchiseptica (ATCC 4617), Escherichia coli (ATCC 15224), and Enterobacter aerogenes (ATCC 13048)) cultured in nutrient broth at $37^{\circ} \mathrm{C}$ for $24 \mathrm{~h}$ were used. A sterile 96-well plate was labeled and serial dilutions were performed with 200, 100, 50, 25, 12.5, 6.25, 3.12, and $1.56 \mu \mathrm{gmL}^{-1}$ final concentration. Then $190 \mu \mathrm{L}$ of bacterial inoculum was added to each well compared with McFarland turbidity standard. A column with a broad spectrum antibiotic as positive control (kanamycin sulfate), negative control 
(DMSO), and blank (nutrient broth) were used on each plate. The experiment was performed in triplicate and incubated at $37^{\circ} \mathrm{C}$. After $24 \mathrm{~h}$, to each well $20 \mu \mathrm{L}$ of TTC indicator solution was added and plates were incubated at $37^{\circ} \mathrm{C}$ for $15-$ 20 minutes and change in colour was determined visually. Colour change from red to pink was recorded as negative (viable bacteria) and no colour change was considered as positive (dead bacteria). The lowest concentration at which no colour change appeared was taken as MIC value.

2.3.7. Antifungal Assay (6-Well Plate Dilution Method). The compounds were screened for their antifungal activity by agar plate dilution method [29] with modifications. Two strains Aspergillus flavus (FCBP 0064) and Fusarium solani (FCBP 0291) cultured on SDA at $28^{\circ} \mathrm{C}$ for $24 \mathrm{~h}$ were used. Test compound with $200,100,50,25$, and $12.5 \mu \mathrm{gmL}^{-1}$ final concentration was poured in each well of 6-well plate. After solidification each well was inoculated with $4 \mathrm{~mm}$ fungal mycelia. Terbinafine and DMSO served as positive control and negative control, respectively. Plates were incubated at $28^{\circ} \mathrm{C}$ for $24 \mathrm{~h}$. Antifungal activity was calculated by measuring the growth diameter of fungus and MIC value was taken as the lowest concentration at which no growth appeared.

\section{Results and Discussion}

\subsection{Spectral Characterization}

3.1.1. FTIR Spectroscopy. The FTIR spectra of aromatic amines (A-1A, A-2A, and A-3A) exhibited characteristic broad absorption bands at $1225-1242 \mathrm{~cm}^{-1}$ due to $\mathrm{C}-\mathrm{O}-$ C vibration, $1587-1608 \mathrm{~cm}^{-1}$ due to $v_{\mathrm{C}=\mathrm{C}}$ of aromatic ring vibrations, and 3391-3468 (asymmetric) and 3315-3372 (symmetric) $\mathrm{cm}^{-1}$ because of $\mathrm{N}-\mathrm{H}$ stretching bands [30].

3.1.2. ${ }^{1} \mathrm{H}$ and ${ }^{13} \mathrm{C}$ NMR Spectral Analysis. The ${ }^{1} \mathrm{H}$ NMR spectra showed characteristic signals in the region 4.62$3.63 \mathrm{ppm}$ corresponding to primary aromatic amine protons. Phenyl protons are present in all the compounds which are verified by the appearance of multiplets at $8.25-6.23 \mathrm{ppm}$ according to the substituents attached. The characteristic singlets at $3.99,4.04$, and $4.01 \mathrm{ppm}$ were due to resonance of amino group protons $\left(-\mathrm{NH}_{2}\right)$ whereas phenyl protons appeared as multiplets in the ranges of 7.33-6.57, 7.89-6.23, and 8.25-6.61 ppm for A-1A, A-2A, and A-3A, respectively.

${ }^{13} \mathrm{C}$ NMR spectroscopic studies also confirmed the formation of all the aromatic amines. The carbon atoms of the aromatic rings attached directly to the oxygen atoms of ether linkage were strongly deshielded showing downfield signals at $157.62,157.49$, and 155.25 ppm for A-1A, A-2A, and A-3A, respectively [31].

3.1.3. Mass Spectral Studies. The mass spectral data of the aromatic amines confirms their formation as molecular ion peaks are obtained at $(\mathrm{m} / \mathrm{z}) 185$ for A-1A and 235 for A-2A and A-3A. The mass spectra of the compounds display molecular ions as base peaks.
TABLE 1: Cytotoxic activity of the amine compounds in brine shrimp cytotoxicity assay.

\begin{tabular}{lcc}
\hline Sr. number & Compound code & $\mathrm{LD}_{50}$ value $\left(\mu \mathrm{gml}^{-1}\right)$ \\
\hline 1 & $\mathrm{~A}-\mathrm{A}$ & 0.28 \\
2 & $\mathrm{~A}-1 \mathrm{~A}$ & 0.50 \\
3 & $\mathrm{~A}-2 \mathrm{~A}$ & 0.16 \\
4 & $\mathrm{~A}-3 \mathrm{~A}$ & 1.0 \\
5 & Vincristine sulphate & 1.0 \\
\hline
\end{tabular}

$\mathrm{LD}_{50}$ : lethal dose that killed $50 \%$ of shrimps.

\subsection{Biological Evaluation}

3.2.1. Brine Shrimp Cytotoxicity Assay. To screen out the biologically active compounds, brine shrimp cytotoxicity assay was performed and results are summarized in Table 1. Brine shrimp cytotoxicity assay serves as prescreen test for the identification of bioactive compounds to evaluate anticancer potential of any compound. All the tested compounds are highly cytotoxic with $\mathrm{LD}_{50}$ value as low as $0.16 \mu \mathrm{gmL}^{-1}$ (Table 1). It is important to note that these compounds are more potent than the vincristine sulphate (positive control) which means that these compounds have strong potential for the anticancer screening.

3.2.2. Potato Disc Antitumor Assay. As the compounds showed good cytotoxic activity, in the prescreen assay, they were screened for possible antitumor activity by using potato disc tumor assay and results are summarized in Table 2 . The compounds A-A, A-1A, and A-2A showed significant antitumor activity with $\mathrm{IC}_{50}$ values $30.47,67.45$, and $12.2 \mu \mathrm{gmL}^{-1}$, respectively. The results were compared with that of the positive control, vincristine sulphate $\left(5.1 \mu \mathrm{gmL}^{-1}\right)$, which predicts the anticancer nature of compounds.

3.2.3. DNA-Drug Interaction Assay. For the evaluation of the potential of an anticancerous compound, study of its binding to the DNA is the key step of drug innovation. The drug binding to DNA has been characterized through absorption titrations [32]. Generally, when drugs intercalate with DNA, blue shift or red shift is observed in the absorption spectra [33]. Additionally, increase or decrease in absorbance is also observed when drugs bind with the grooves of DNA [34]. Initially, UV-spectra of the compounds in SM (solvent mixture) consisting of methanol and water $(9: 1)$ were recorded in terms of $\lambda_{\max }$. The compound A-3A showed hyperchromic effect along with blue shift of $15 \mathrm{~nm}$ which is indicative of higher susceptibility for intercalation with DNA. Furthermore, all of the compounds A-A, A-1A, A-2A, and A$3 \mathrm{~A}$ with $\lambda_{\max } 206,241,222$, and $215 \mathrm{~nm}$, respectively, showed hyperchromism with increasing the concentrations of the DNA (Figure 1), suggesting their groove binding property. Groove binding compounds are of practical importance for the development of new anticancer agents because they localize in the nuclear DNA of whole cells and possess a profile of promising biological activity [35]. It has been reported previously that the interaction of copper(II) complex with DNA by increase in DNA concentration results in hyperchromic 
TABLE 2: Tumor inhibition activity of the amine compounds in potato disc antitumor assay.

\begin{tabular}{lccccc}
\hline Sr. number & Compound code & \multicolumn{2}{c}{ Percentage inhibition } & $\mathrm{IC}_{50} \mu \mathrm{gml}^{-1}$ \\
\hline 1 & A-A & $1000 \mu \mathrm{gml}^{-1}$ & 57.5 & 12.5 & 30.47 \\
2 & A-1A & 57.5 & 52.5 & 15 & 67.45 \\
3 & A-2A & 100 & 95 & 13.3 & 12.2 \\
4 & A-3A & 25 & 22.5 & 10 & $>1000$ \\
5 & Vincristine sulphate & 100 & 100 & 9.5 & 5.1 \\
\hline
\end{tabular}

$\mathrm{IC}_{50}$ : inhibitory concentration that inhibited $50 \%$ tumors.

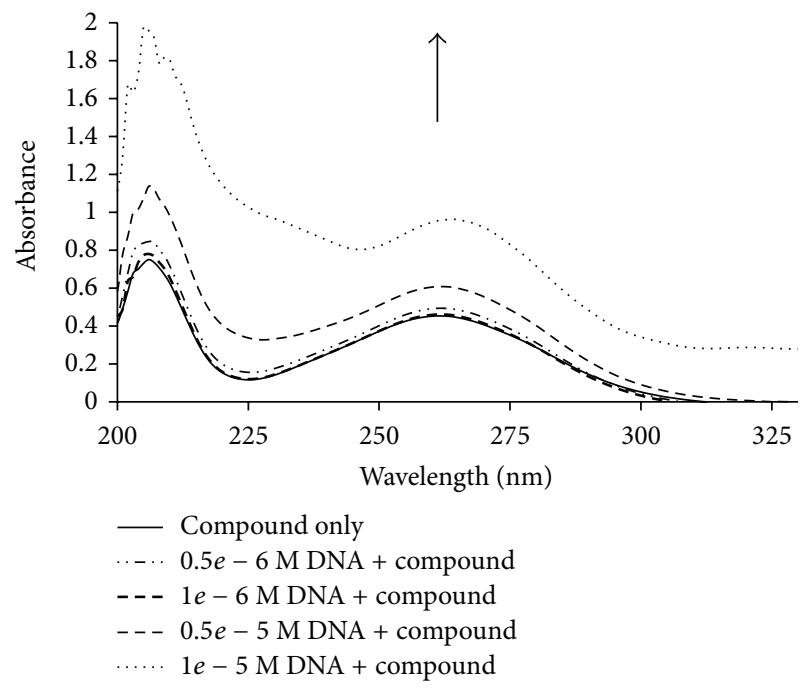

(a)

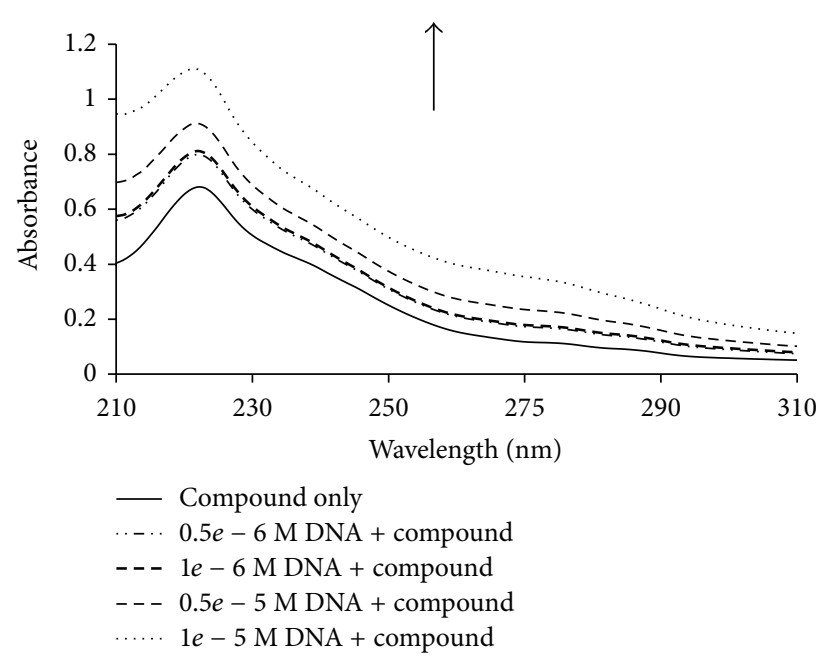

(c)

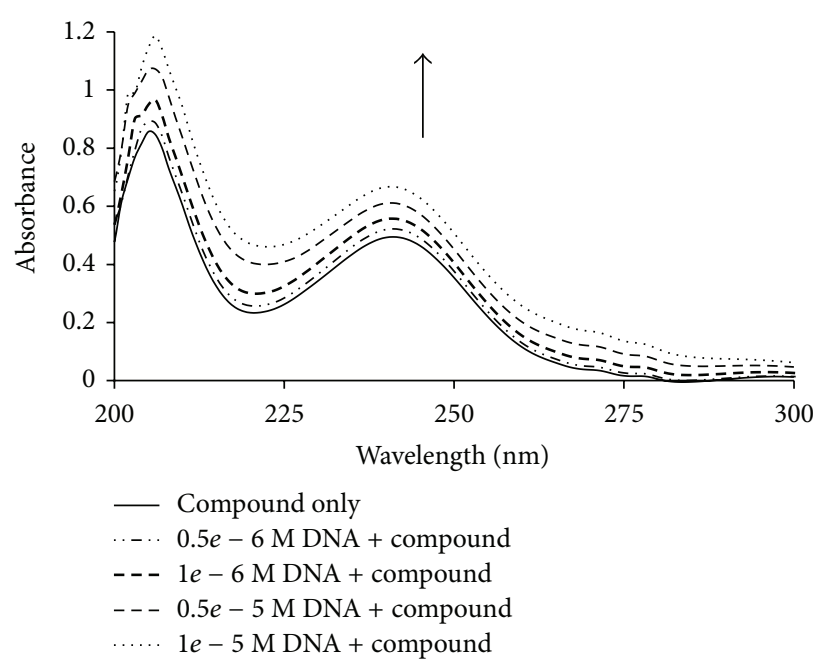

(b)

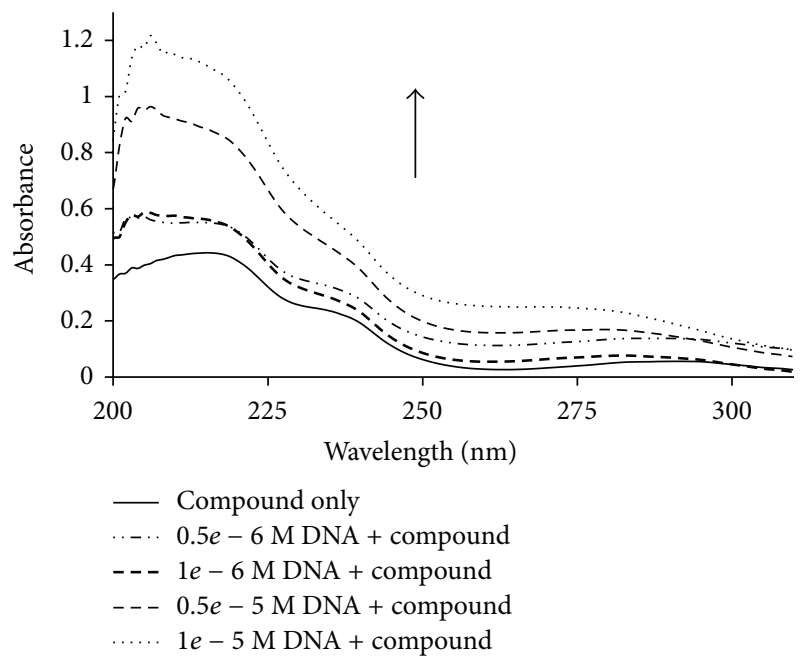

(d)

Figure 1: Absorption spectrum of (a) A-A, (b) A-1A, (c) A-2A, and (d) A-3A in the absence and presence of human DNA. The arrow direction shows trend in the change of absorbance.

effect. This spectral change might be indicative of groove binding as the organic ligand-copper coordination facilitates the formation of Van der Waals contacts or hydrogen bonds during interaction with DNA grooves [36]. In another study two complexes $\mathrm{C}_{10} \mathrm{H}_{22} \mathrm{~N}_{2} \mathrm{O}_{5} \mathrm{SnCl}_{2}$ and $\mathrm{C}_{10} \mathrm{H}_{22} \mathrm{~N}_{2} \mathrm{O}_{5} \mathrm{ZrCl}_{2}$ exhibited intraligand absorption bands in the UV. By the addition of increasing amounts of CT-DNA to complexes, a sharp hyperchromic effect in the absorption bands with a moderate red shift of 5 and $3 \mathrm{~nm}$, respectively, was observed. Hyperchromic effect reflects the corresponding changes of 
TABLE 3: DPPH free radical scavenging activity of the amine compounds.

\begin{tabular}{lcccccc}
\hline \multirow{2}{*}{ Sr. number } & Compound code & \multicolumn{2}{c}{ Percentage scavenging } & $\mathrm{IC}_{50} \mu \mathrm{gml}^{-1}$ \\
\hline 1 & & $200 \mu \mathrm{gml}^{-1}$ & $66.66 \mu \mathrm{gml}^{-1}$ & $22.22 \mu \mathrm{gml}^{-1}$ & $7.4 \mu \mathrm{gml}^{-1}$ \\
2 & $\mathrm{~A}-\mathrm{A}$ & 60.74 & 51.85 & 45.42 & 29.81 & 47.29 \\
3 & $\mathrm{~A}-1 \mathrm{~A}$ & 67.51 & 59.65 & 42.18 & 28.47 & 32.50 \\
4 & $\mathrm{~A}-2 \mathrm{~A}$ & 59.26 & 51.11 & 39.26 & 26.59 & 61.61 \\
5 & A-3A & 63.70 & 51.34 & 36.80 & 24.59 & 59.66 \\
\hline
\end{tabular}

$\mathrm{IC}_{50}$ : inhibitory concentration that scavenged $50 \%$ free radicals.

TABLE 4: DNA protection activity of the amine compounds in DNA damage assay.

\begin{tabular}{lcccc}
\hline $\begin{array}{l}\text { Sr. } \\
\text { number }\end{array}$ & Compound code & \multicolumn{3}{c}{$\begin{array}{l}\text { DNA protection activity at } \\
\text { different concentrations } \\
1000 \mu \mathrm{gml}^{-1}\end{array}$} \\
\hline 1 & A-A & +++ & +++ & ++ \\
2 & A-1A & +++ & +++ & ++ \\
3 & A-2A & +++ & +++ & ++ \\
4 & A-3A & +++ & +++ & ++ \\
\hline
\end{tabular}

++ : significant protection; ++: good protection.

DNA in its conformation and structure after the complexDNA interaction has occurred [37].

3.2.4. DPPH Free Radical Scavenging Assay. DPPH free radical scavenging activity of the compounds was evaluated spectrophotometrically at four different concentrations $\left(200,66.6,22.2\right.$, and $\left.7.4 \mu \mathrm{gmL}^{-1}\right)$. All compounds showed significant antioxidant potential with $\mathrm{IC}_{50}$ values of 47.29 , $32.50,61.61$, and $59.66 \mu \mathrm{gmL}^{-1}$, respectively, in comparison with ascorbic acid $\left(9.6 \mu \mathrm{gmL}^{-1}\right)$. Results of this assay are summarized in Table 3.

3.2.5. DNA Damage Assay. Keeping in view the good antioxidant activity, the compounds were screened for their protection against DNA damage assay at three concentrations $\left(1000,100\right.$, and $\left.10 \mu \mathrm{gmL}^{-1}\right)$. This assay based on the attack of ${ }^{\bullet} \mathrm{OH}$ produced from the Fenton reaction and super coiled plasmid DNA is broken into open circular or linear form. By analyzing the intensity of bands formed on $1 \%$ agarose gel, results were recorded and tabulated (Table 4, Figures 2 and 3). All the compounds showed significant protection at 1000 and $100 \mu \mathrm{gmL}^{-1}$ concentrations, while showing good protection at $10 \mu \mathrm{gmL}^{-1}$ concentration. The results indicate that these compounds could be regarded as potential antioxidant and anticancerous agents after further investigation.

3.2.6. Antibacterial Assay. Antibacterial activity was determined through 96-well plate method using 2,3,5triphenyltetrazolium chloride (TTC) as indicator which enzymatically reduced to red 1,3,5-triphenylformazan (TPF) in living tissues due to the activity of various dehydrogenases [38]. Kanamycin sulfate was used as positive control and
MIC was calculated against B. bronchiseptica $\left(125 \mu \mathrm{gmL}^{-1}\right)$, S. aureus $\left(32 \mu \mathrm{gmL}^{-1}\right)$, E. aerogenes $\left(30 \mu \mathrm{gmL}^{-1}\right)$, M. luteus $\left(32 \mu \mathrm{gmL}^{-1}\right)$, and E. coli $\left(32 \mu \mathrm{gmL}^{-1}\right)$. The results showed that compound A-1A (Figure 3) exhibited significant antibacterial activity against all the tested strains $B$. bronchiseptica, $S$. aureus, E. aerogenes, $M$. luteus, and $E$. coli with MIC values of $25,50,50,100$, and $100 \mu \mathrm{gmL}^{-1}$, respectively. This means that compound A-1A can act as a broad spectrum antibiotic. This is a simple and rapid method from which accurate MIC (minimum inhibitory concentration) can be generated.

3.2.7. Antifungal Assay. The compounds were tested for their antifungal activity, using 6-well agar dilution method. Here, we report the use of 6 -well plate because the main advantage of the plates is that you can grow six cultures under identical conditions in the same culture plate. Moreover, smaller wells in plates are useful for application of expensive reagents in smaller volumes. Among all the compounds, A$1 \mathrm{~A}$ showed significant antifungal activity against $F$. solani and A. flavus with MIC value $12.5 \mu \mathrm{gmL}^{-1}$ for both. MIC value for terbinafine was calculated against $F$. solani $\left(16 \mu \mathrm{gmL}^{-1}\right)$ and A. flavus $\left(1 \mu \mathrm{gmL}^{-1}\right)$. It is interesting to know that A$1 \mathrm{~A}$ possesses both significant antibacterial and antifungal activity which means that this compound can be used for dual purpose as antibacterial and antifungal agents.

\section{Conclusion}

Three new aromatic amines 1-amino-4-phenoxybenzene (A$1 \mathrm{~A}), 2-(4-a m i n o p h e n o x y)$ naphthalene (A-2A), and 1-(4aminophenoxy) naphthalene (A-3A) were prepared in high purity and high yield. In vitro investigation of the four amine compounds showed that activity ranges from being selective (active in one assay) to being broad spectrum (active in all assays). The compound A-1A was active against all the biological assays which means it can be used as a potential candidate for drug development after advanced investigation. The obtained findings showing significant activity in brine shrimp cytotoxicity assay and antitumor assay provide the evidence for a very strong positive correlation between these two assays and for prediction of some valuable anticancerous principles present in these compounds. On the other hand, the compounds showed significant antioxidant activity and DNA protective effect against oxidative damage. Interestingly, in the DNA-drug interaction study, it was observed that 


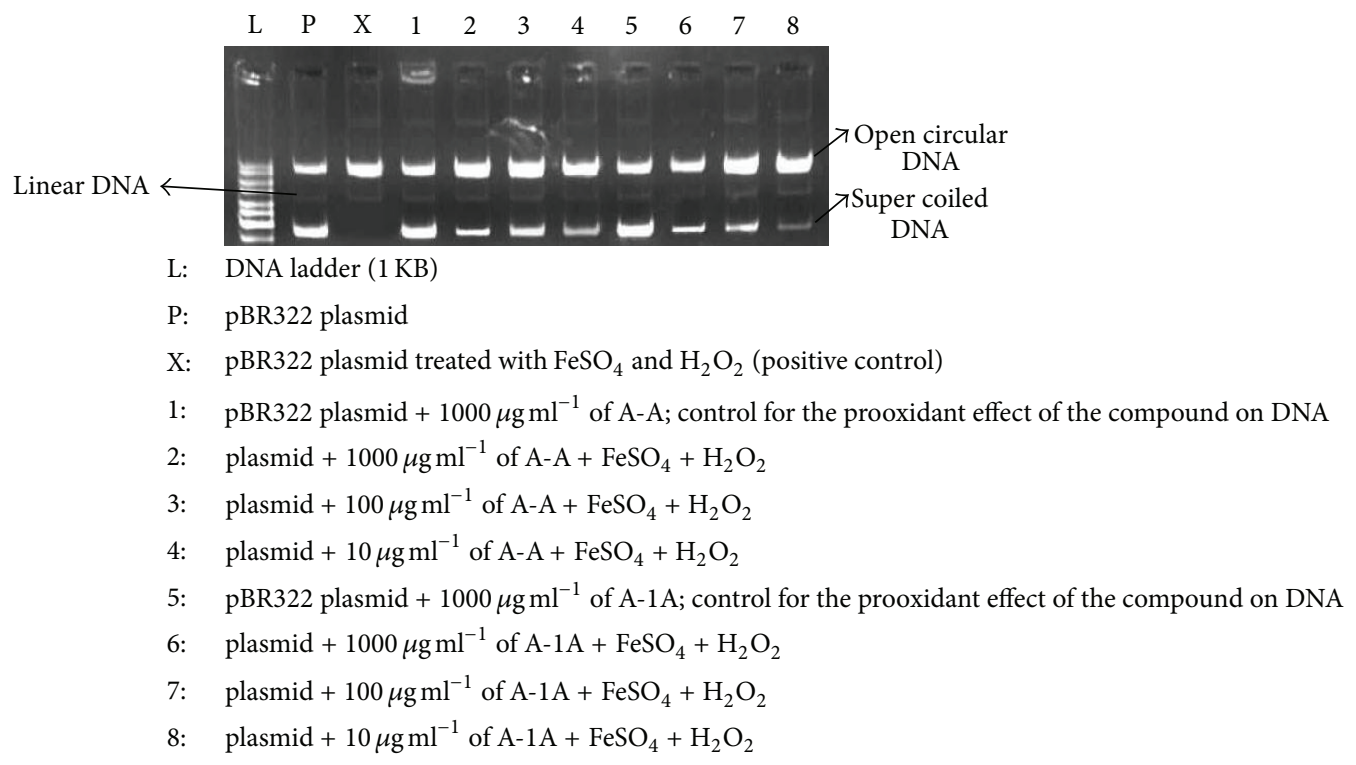

FIgURE 2: Effect of the compounds A-A and A-1A on pBR322 plasmid DNA.

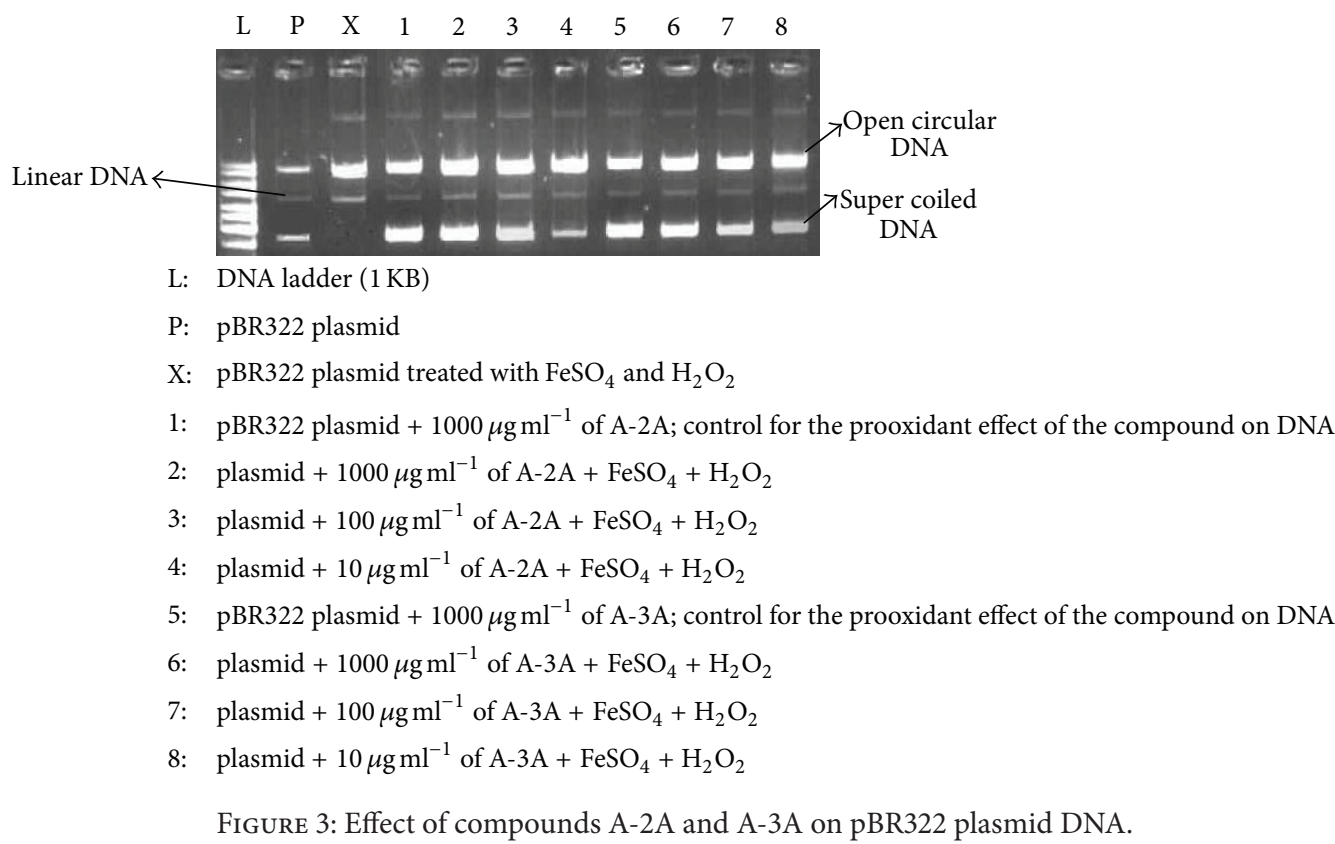

these compounds bind with the grooves of DNA which can affect the binding of transcription factors with DNA and ultimately gene expression leading to the antitumor behavior. The findings of this study support the view that some of these compounds can be a promising source of potential antitumor drugs.

\section{Conflict of Interests}

The authors declare that there is no conflict of interests regarding the publication of this paper.

\section{References}

[1] A. Grirrane, A. Corma, and H. García, "Gold-catalyzed synthesis of aromatic azo compounds from anilines and nitroaromatics," Science, vol. 322, no. 5908, pp. 1661-1664, 2008.

[2] M. N. Ibrahim and S. A. I. Sharif, "Synthesis, characterization and use of Schiff bases as fluorimetric analytical reagents (part II)," E-Journal of Chemistry, vol. 8, no. 1, pp. 180-184, 2011.

[3] Y. Tao, H. Kanoh, L. Abrams, and K. Kaneko, "Mesoporemodified zeolites: preparation, characterization, and applications," Chemical Reviews, vol. 106, no. 3, pp. 896-910, 2006. 
[4] P. R. Buch and A. V. R. Reddy, "Synthesis, characterization and thermal properties of soluble aromatic poly(amide imide)s," Polymer, vol. 46, no. 15, pp. 5524-5532, 2005.

[5] S. Gocan, "Stationary phases for thin-layer chromatography," Journal of Chromatographic Science, vol. 40, no. 10, pp. 538-549, 2002.

[6] N. Farhadyar, A. Rahimi, and A. E. Langroudi, "Preparation and characterization of aromatic amine cured epoxy-silica hybrid inorganic-organic coating via in situ sol-gel process," Iranian Polymer Journal, vol. 14, no. 2, pp. 155-162, 2005.

[7] A. Tapase, N. D. Shinde, and D. Shinde, "Microwave synthesis of $\mathrm{N}$-alkyl aromatic amines from $p$-toluene sulphonamide in presence of phase transfer catalyst," Bulletin of Environment, Pharmacology and Life Sciences, vol. 1, pp. 50-54, 2012.

[8] P. Kumar, B. Narasimhan, D. Sharma, V. Judge, and R. Narang, "Hansch analysis of substituted benzoic acid benzylidene/furan-2-yl-methylene hydrazides as antimicrobial agents," European Journal of Medicinal Chemistry, vol. 44, no. 5, pp. 1853-1863, 2009.

[9] R. M. Barmore, S. R. Logan, and B. C. van Wagenen, "The addition of amines to diisobutylaluminum-imine complexes. Preparation of NPS R-568 hydrochloride," Tetrahedron Letters, vol. 39, no. 21, pp. 3451-3454, 1998.

[10] N. Sithranga Boopathy and K. Kathiresan, "Anticancer drugs from marine flora: an overview," Journal of Oncology, vol. 2010, Article ID 214186, 18 pages, 2010.

[11] C. A. Gomes, T. Girão Da Cruz, J. L. Andrade, N. Milhazes, F. Borges, and M. P. M. Marques, "Anticancer activity of phenolic acids of natural or synthetic origin: a structure-activity study," Journal of Medicinal Chemistry, vol. 46, no. 25, pp. 5395-5401, 2003.

[12] N. Arshad, U. Yunus, S. Razzque et al., "Electrochemical and spectroscopic investigations of isoniazide and its analogs with ds.DNA at physiological pH: evaluation of biological activities," European Journal of Medicinal Chemistry, vol. 47, no. 1, pp. 452461, 2012.

[13] A. Shah, R. Qureshi, A. M. Khan, R. A. Khera, and F. L. Ansari, "Electrochemical behavior of 1-ferrocenyl-3-phenyl-2propen-1-one on glassy carbon electrode and evaluation of its interaction parameters with DNA," Journal of the Brazilian Chemical Society, vol. 21, no. 3, pp. 447-451, 2010.

[14] L. M. Wilhelmsson, N. Kingi, and J. Bergman, "Interactions of antiviral indolo[2,3-b]quinoxaline derivatives with DNA," Journal of Medicinal Chemistry, vol. 51, no. 24, pp. 7744-7750, 2008.

[15] M. S. Shahabuddin, M. Gopal, and S. C. Raghavan, "Intercalating and antitumour activity of 4-Oxopyrimido[ $\left[4^{\prime} ; 5^{\prime}: 4,5\right]$ thieno(2,3-b)quinoline-4(3H)-one," Journal of Cancer Molecules, vol. 3, no. 5, pp. 139-146, 2007.

[16] S. Usha, I. M. Johnson, and R. Malathi, "Modulation of DNA intercalation by resveratrol and genistein," Molecular and Cellular Biochemistry, vol. 284, no. 1-2, pp. 57-64, 2006.

[17] H. M. Siddiqi, A. Afzal, S. Sajid, and Z. Akhter, "Synthesis, characterization and thermal oxidative stability of rigid epoxy polymers cured from aromatic mono- and di-amines," Journal of Polymer Research, vol. 20, no. 2, article 41, 2013.

[18] A. I. Vogel, Textbook of Practical Organic Chemistry, Longman, London, UK, 5th edition, 1989.

[19] J. K. Im and J. C. Jung, "Synthesis and properties of polyimides derived from N-[4-(4- aminophenyloxy)phenyl]-4aminophthalimide," Polymer, vol. 41, no. 24, pp. 8709-8716, 2000 .
[20] J. C. Jung and S.-B. Park, "Synthesis and characterization of polyimides from imidazole-blocked 2,5-bis[(n-alkyloxy)methyl]-1,4-benzene diisocyanates and pyromellitic dianhydride," Journal of Polymer Science Part A: Polymer Chemistry, vol. 34, no. 3, pp. 357-365, 1996.

[21] S. Z. Siddiqui, M. A. Abbasi, M. Aziz-ur-Rehman et al., "Synthesis pharmacological evaluation, molecular docking and cytotoxicty studies on some $n$-substituted 5-[(4-chlorophenoxy)methyl]-1,3,4-oxadiazole-2yl-2-sulfanyl acetamides," Indo American Journal of Pharmaceutical Research, vol. 4, no. 8, p. 3603, 2014.

[22] D. J. Finney, Probit Analysis, Cambridge University Press, Cambridge, UK, 1971.

[23] G.-F. Qi, Z.-Y. Yang, and D.-D. Qin, "Synthesis, characterization and DNA-binding properties of the $\mathrm{Cu}(\mathrm{II})$ complex with 7-methoxychromone-3-carbaldehyde-benzoylhydrazone," Chemical and Pharmaceutical Bulletin, vol. 57, no. 1, pp. 69-73, 2009.

[24] C. Liu, S. Liu, Y. Wang et al., "Synthesis, cytotoxicity, and DNAbinding property of berberine derivatives," Medicinal Chemistry Research, vol. 23, no. 4, pp. 1899-1907, 2014.

[25] A. Ullah, F. L. Ansari, S. Nazir, and B. Mirza, "Combinatorial synthesis, lead identification, and antitumor study of a chalcone-based positional-scanning library," Chemistry \& Biodiversity, vol. 4, no. 2, pp. 203-214, 2007.

[26] N. Haq, Z. Akhter, S. Yameen, H. M. Siddiqi, B. Mirza, and A. Rifat, "Synthesis and biological evaluations of some Schiffbase esters of ferrocenyl aniline and simple aniline," Journal of Organometallic Chemistry, vol. 694, no. 14, pp. 2198-2203, 2009.

[27] R. Pal, V. Kumar, A. K. Gupta, V. Beniwal, and G. K. Gupta, "Synthesis, characterization, and DNA cleavage study of dehydroacetic acid based tridentate Schiff's base and its metal complexes of first transition series," Medicinal Chemistry Research, vol. 23, no. 9, pp. 4060-4069, 2014.

[28] S. D. Sarker, L. Nahar, and Y. Kumarasamy, "Microtitre platebased antibacterial assay incorporating resazurin as an indicator of cell growth, and its application in the in vitro antibacterial screening of phytochemicals," Methods, vol. 42, no. 4, pp. 321324, 2007.

[29] M. I. Choudhary, D. Shahwar, Z. Parveen, A. Jabbar, I. Ali, and A. Rahman, "Antifungal steroidal lactones from Withania coagulance," Phytochemistry, vol. 40, no. 4, pp. 1243-1246, 1995.

[30] M. S. Butt, Z. Akhter, M. Zafar-uz-Zaman, and H. M. Siddiqi, "Synthesis and characterization of some Schiff-base-containing polyimides," Colloid and Polymer Science, vol. 286, no. 12, pp. 1455-1461, 2008.

[31] M. S. Butt, Z. Akhtar, M. Zafar-uz-Zaman, and A. Munir, "Synthesis and characterization of some novel aromatic polyimides," European Polymer Journal, vol. 41, no. 7, pp. 1638-1646, 2005.

[32] M. T. Carter, M. Rodriguez, and A. J. Bard, "Voltammetric studies of the interaction of metal chelates with DNA. 2. Tris-chelated complexes of cobalt(III) and iron(II) with 1,10phenanthroline and 2,2' -bipyridine," Journal of the American Chemical Society, vol. 111, no. 24, pp. 8901-8911, 1989.

[33] R. Meneghini, "Iron homeostasis, oxidative stress, and DNA damage," Free Radical Biology and Medicine, vol. 23, no. 5, pp. 783-792, 1997.

[34] B. Tian and Y. Hua, "Concentration-dependence of prooxidant and antioxidant effects of aloin and aloe-emodin on DNA," Food Chemistry, vol. 91, no. 3, pp. 413-418, 2005. 
[35] B. S. P. Reddy, S. M. Sondhi, and J. W. Lown, "Synthetic DNA minor groove-binding drugs," Pharmacology and Therapeutics, vol. 84, no. 1, pp. 1-111, 1999.

[36] S. Dey, S. Sarkar, H. Paul, E. Zangrando, and P. Chattopadhyay, "Copper(II) complex with tridentate N donor ligand: Synthesis, crystal structure, reactivity and DNA binding study," Polyhedron, vol. 29, no. 6, pp. 1583-1587, 2010.

[37] F. Arjmand and A. Jamsheera, "DNA binding studies of new valine derived chiral complexes of tin(IV) and zirconium(IV)," Spectrochimica Acta Part A: Molecular and Biomolecular Spectroscopy, vol. 78, no. 1, pp. 45-51, 2011.

[38] H. L. Brown, A. H. M. van Vliet, R. P. Betts, and M. Reuter, "Tetrazolium reduction allows assessment of biofilm formation by Campylobacter jejuni in a food matrix model," Journal of Applied Microbiology, vol. 115, no. 5, pp. 1212-1221, 2013. 

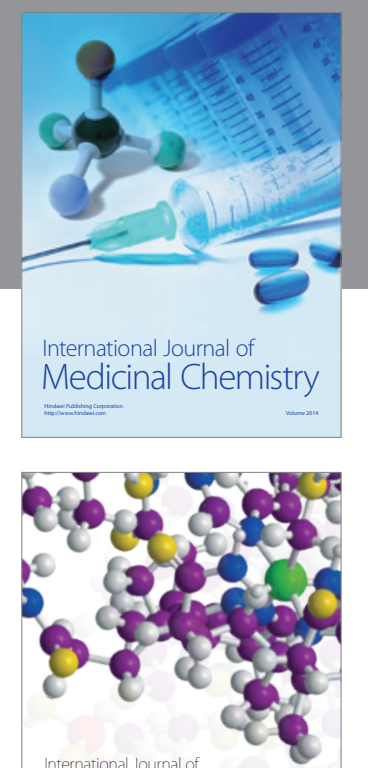

\section{Carbohydrate} Chemistry

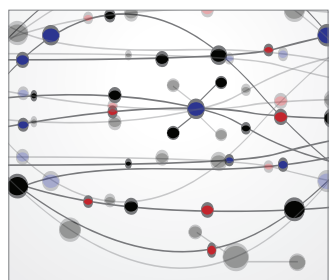

The Scientific World Journal
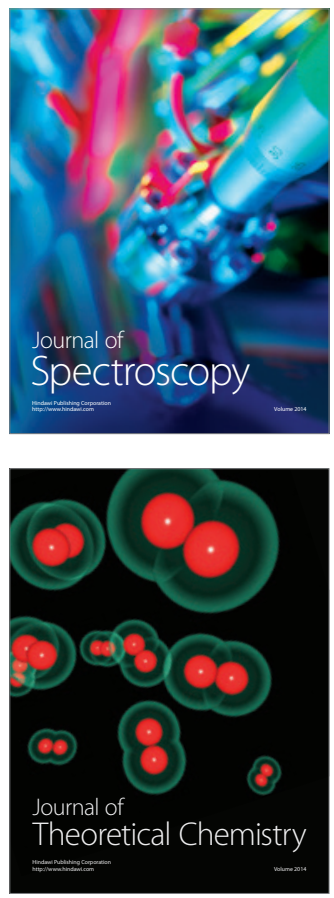
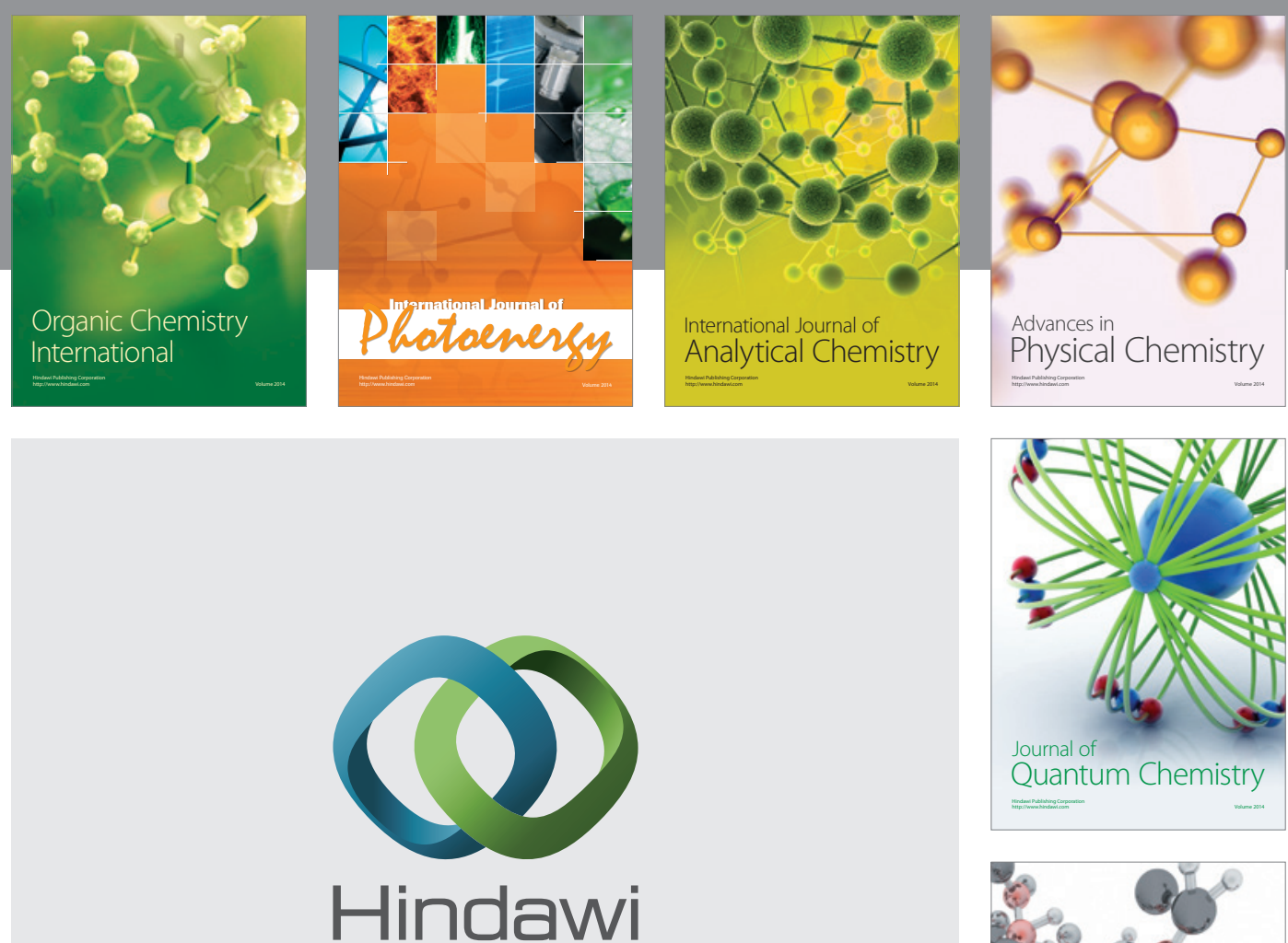

Submit your manuscripts at

http://www.hindawi.com

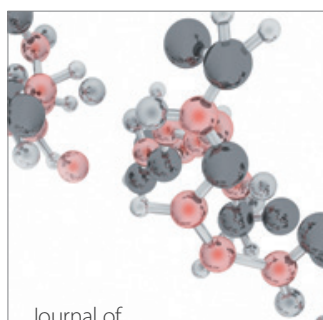

Analytical Methods

in Chemistry

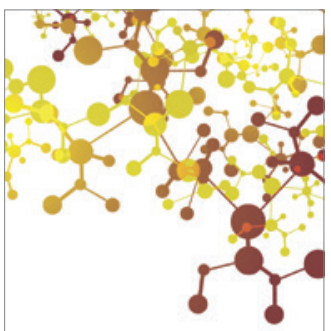

Journal of

Applied Chemistry

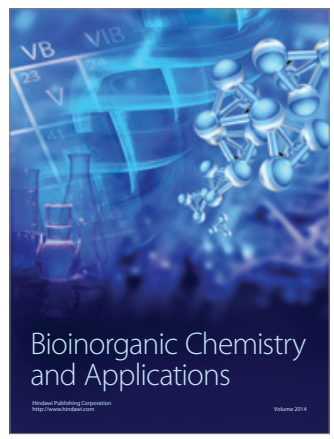

Inorganic Chemistry
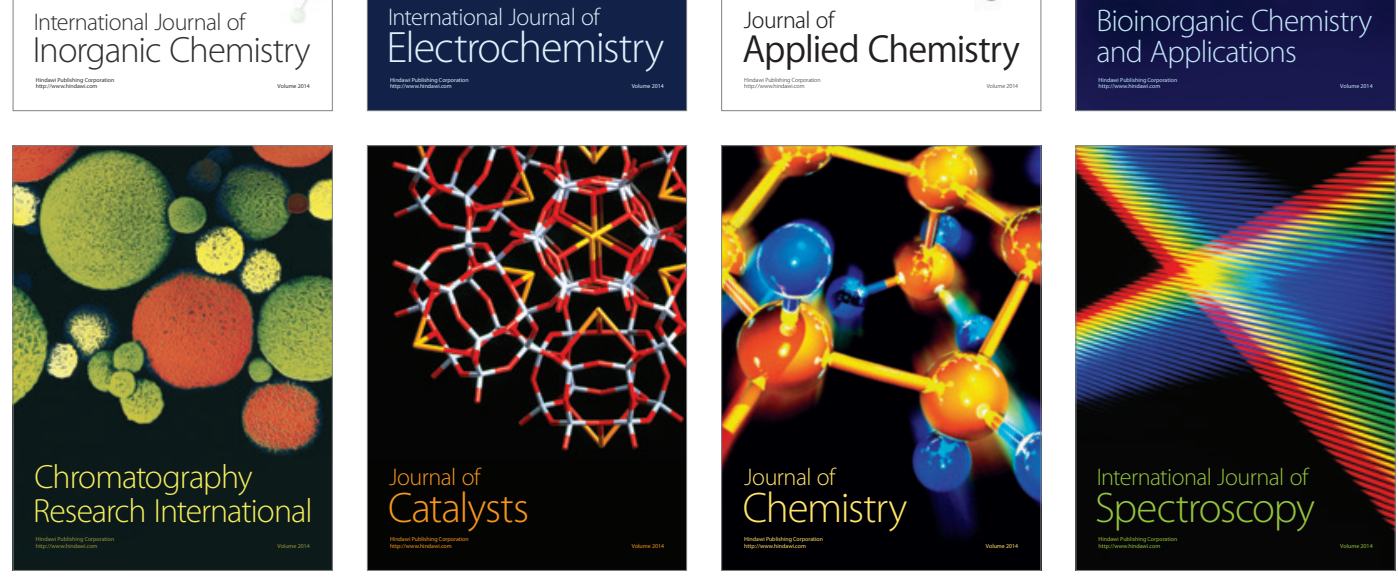